\title{
Multilateral donors and the security-development nexus: Discourse and practice in conflict-affected states
}

\begin{abstract}
This article assesses how the 'security-development nexus' has impacted multilateral aid to conflict-affected states; an area until now understudied. Using a mixed methods approach, we examine both the policy discourse and aid commitments of the major multilateral donors: the European Commission, the World Bank, and the UNDP. We investigate the extent to which these donors fund the sectors identified within the policy discourse as crucial to ensuring peace and stability - democratisation and peace, conflict, and security activities - and examine the impact of 'Western' security concerns on multilateral aid in conflict-affected states. Our new data indicate that in contrast to policy discourse, postconflict states receive no more multilateral funding for democracy building than states which have not suffered from conflict and furthermore, that in the context of the securitydevelopment nexus, multilateral aid to conflict-affected states is influenced by the key transnational security concerns of Western states. These results point to a potentially dangerous gap between policy and actual aid commitments, ignore the long-term nature of development and weaken the impartiality of multilateral aid.
\end{abstract}

\section{Key words}

Multilateral donors, development aid, conflict, security, discourse, security-development nexus

\section{Acknowledgements}


The authors are grateful for the comments of two anonymous reviewers on an earlier draft of this paper. We are also grateful for funding from the Faculty of Humanities and Social Science, University of Portsmouth, which enabled us to carry out this research. 


\section{Introduction}

The idea that conflict and instability in the Global South cannot be separated from development considerations and may have wider security implications, particularly for the Global North, has become pervasive within development discourse. Whilst the impact of this so-called 'security-development nexus' on bilateral aid has been investigated ${ }^{1}$, the extent and manner to which it has impacted multilateral aid remains understudied. In response, this research firstly assesses the extent to which both multilateral policy and practice in conflictaffected states reflect the security-development nexus.

We find that the policy discourse of multilateral donors strongly upholds the idea that inclusive democratic political structures in conflict-affected states are essential to establishing long-term peace and security. However, we also find that in practice, conflict-affected states receive no more multilateral funding for democracy-building programmes than states that have not suffered conflict.

Secondly, for key funders of these multilateral institutions, including the US and the $\mathrm{UK},{ }^{2}$ conflict and fragility in the Global South are perceived to threaten national security through increasing migration and the opportunity for terrorist groups to operate. In recognition of this, this article investigates the influence of these security concerns on multilateral aid to conflict-affected states. Our results suggest that these concerns indeed influence this type of aid.

We conclude then that there is a gap between the stated priorities of multilateral donors and their actual aid commitments. This finding may reflect the short-termist nature of aid programming, with long-term investment in democratisation activities relegated in favour of conflict-resolution activities, which have been shown to exacerbate instability and conflict $^{3}$. Furthermore, we find that within the context of the security-development nexus, 
multilateral aid to conflict-affected states reflects the transnational security concerns of major Western states.

\section{The security-development nexus and multilateral donors}

Security concerns largely dictated donors' development policies during the Cold War. After a brief period in which such concerns were delinked from development, with donors reluctant to engage in conflict zones, ${ }^{4}$ the mid-1990s saw a resurgence of the link between security and development. However, whilst during the Cold War, development aid was provided with the strategic aim of bolstering capitalism or communism, in its current form the security-development nexus holds that conflict, fragility, and instability in the global South may constitute a threat to Western security. ${ }^{5}$ The extent to which the policy and, crucially, practice of multilateral donors have been influenced by this security-development nexus and, within this context, by the security concerns of their main funders is the central question of this article. In addressing it, we examine the policy discourse and aid-provision of the three major multilateral channels of delivering development aid: the World Bank's International Development Association ${ }^{6}$ (IDA), the United Nations Development Programme (UNDP), and - for European Union (EU) donors - the European Commission (EC).

Multilateral donors have been described as less susceptible to political, commercial, and strategic considerations than bilateral donors and relatively more responsive to recipients' need. ${ }^{7}$ There is also, however, evidence indicating that multilateral aid is not insulated from the interests of key member states. Research suggests that the Bretton Woods institutions ${ }^{8}$ align their policies with the interests of their key Western funders ${ }^{9}$ and attempt to impose a Western development model on aid-recipient states. ${ }^{10}$ The World Bank derives 96 per cent ${ }^{11}$ of its funding annually from the Organisation for Economic Co-operation and Development (OECD) and EU member countries and has been criticised as beholden in its policies to the United States and their Western allies. ${ }^{12}$ 
Whilst the UNDP is also predominantly funded by Western states ${ }^{13}$, it has generally been understood as less influenced by Western interests than the Bretton Woods institutions,${ }^{14}$ although Berthelemy ${ }^{15}$ found that the UNDP provided more aid to major global arms importers. The European Union as a regional institution of politically and socially integrated states can be expected to represent the interests of its members. ${ }^{16}$ Indeed, there is evidence that the European Commission accounts for member states' interests when making aid-allocation decisions,${ }^{17}$ even though Furness and Gänzle ${ }^{18}$ argue that the coherence of the security-development nexus within such aid allocation is constrained by collective-action challenges as well as bureaucratic and institutional complexities.

Moving beyond the existing literature, we investigate (1) the extent to which the security-development nexus, prevalent in current bilateral policy discourse, is reflected in multilateral policy discourse, (2) how this discourse may have affected multilateral aid flows in practice, and (3) the extent to which, in the context of the security-development nexus, the key transnational security concerns of Western states are reflected in multilateral aid provision to conflict-affected states. In distinction from previous studies, we do not aggregate the multilateral aid but examine each donor separately.

The remainder of the article is organised as follows. First, we examine the development policy discourse of the European Commission, World Bank, and UNDP in order to establish the extent to which it reflects the security-development nexus and to identify the type of programmes that are understood to contribute to peace and security in conflictaffected states. Drawing on this analysis, we then construct four testable hypotheses regarding multilateral aid commitments in conflict-affected states and introduce the article's theoretical framework, the data used, and the methods employed to analyse them. The final sections present the results obtained and discuss their policy and political implications, and consider a number of explanations for our findings. 


\section{The security-development nexus within policy discourse}

To what extent does the policy discourse of the three multilateral donors reflect the trend towards securitisation ${ }^{19}$ established within the bilateral policy discourse? And what does this discourse suggest about the type of programmes to be funded in conflict-affected and fragile states? In order to answer these questions, we undertook a systematic data collection and analysis of development policy documents from our three donors spanning the last two decades. Major policy documents such as World Development Reports and reports setting out overarching development strategies were examined, along with policy documents specifically dealing with conflict, security, and development. Using qualitative analysis software an iterative processes of analysis was used with text coded to categories and patterns identified $^{20}$. Given the questions above, primary-cycle coding involved coding references to security, conflict/instability and fragile states, as well as to refugee movements and terrorism etc., to identify how these concepts were understood in the discourse. Secondary-cycle coding sought to identify patterns and links between these concepts - for example, how 'fragile states' are understood in relation to 'global security'. Secondary-cycle coding also sought to establish the types of programmes deemed appropriate in conflict affected and postconflict states. This eventually led to hierarchical coding of programmes where various codes were placed under umbrella categories to make sense of them. The results of this qualitative analysis are as follows.

Within the development policy discourse, the approach to conflict-affected states consists of two interrelated assumptions. The first is that underdevelopment and conflict in the Global South are mutually reinforcing and that there can be no security without development and vice-versa. ${ }^{21}$ All three multilateral donors agree on this point.

In addition, the European Commission holds that through terrorism, refugee flows, and international crime, instability and conflict in the Global South are sources of 
international insecurity. ${ }^{22}$ For example, according to the European commission 'fragile states, weak governance, socio-economic, and socio-political grievances provide uninhibited operating space for violent extremists' ${ }^{23}$ In contrast, whilst the UNDP is concerned about global challenges such as transnational organised crime and violent extremism, it is careful not to differentiate between conflict-affected/fragile states who have the potential to increase insecurity at an international level and stable democratic states who may be under threat from the former, arguing that the 'duality between developed and developing states has lost relevance'. ${ }^{24}$ As such, according to the UNDP, new transnational challenges including terrorism, climate change and migration cannot be tackled within the confines of 'aid' as it is traditionally conceptualised. ${ }^{25}$ With near universal membership and representation, it makes sense for the UNDP not to problematise the Global South in relation to the Global North, but to recognise challenges that negatively impact all states. The EU on the other hand represents its European members, many of whom have increasing securitised what are perceived as negative flows from the Global South, including terrorism and refugees. ${ }^{26}$

For the World Bank, conflict-affected and fragile states are central to its work and the institution recognises 'new threats' emanating from these states such as terrorism and trafficking. ${ }^{27}$ However, the World Bank also understands that conflict and violence should 'no longer [be] seen as restricted to fragile states; in fact, fragility and violence affect nearly all states'.28

The second assumption guiding all three institutions is that development aid can be used to enhance security and prevent conflict in the Global South. ${ }^{29}$ The European Commission argues that development aid plays a crucial role in stabilising conflict situations, whilst the UNDP maintains that international finance including development aid can help build the inclusive social contract underpinning peaceful societies. ${ }^{30}$ 
The policy discourse of the three donors does therefore to some extent mirror the security-development nexus established in the policy discourse of bilateral donors. ${ }^{31}$ In order to assess the extent to which this discourse has affected multilateral aid practice, we need to ascertain the types of programmes justified by the security-development nexus within the multilateral donors' policy discourse. According to the policy discourse of all three donors, reducing and preventing future conflict and ensuring long-term peace requires two types of development interventions. The first seeks to encourage the development of democratic, inclusive societies, which respect human rights and promote gender equality. According to the UNDP, a '...solid, inclusive social contract, underpinned by democratic governance can help maintain an equilibrium between competing interests and reduce fragility and the likelihood of organised violence'.$^{32}$ Even more specifically, the EC argues that 'strengthening the fundamental building blocks of equitable development, human rights, governance and the rule law' are key in tackling violent extremism. ${ }^{33}$ Similarly, the World Bank recognises that, whilst it may be difficult, 'the high road to peace and prosperity is best approached through a consensual form of politics featuring inclusive political coalitions ... and ... accountable institutions', 34

The second type of development programmes understood by multilateral donors as able to contribute to peace and security in conflict-affected states are explicit conflictprevention and resolution measures. These include the disarmament of civilians, reform of the security, police, and justice sectors, and civilian 'peace-building' activities. ${ }^{35}$ Conflictprevention work has become a fundamental aspect of global development policy, pursued by all major development institutions including the three assessed in this study. ${ }^{36}$

In summary, the UNDP, the EC, and the World Bank agree that peace and development in the Global South are indivisible and that development aid can and should be used to contribute to peace and security in conflict-affected countries. All three multilateral 
donors advocate the view that development aid can mitigate conflict through (1) democratisation programmes (alternatively referred to, particularly by the World Bank, as good-governance programmes) and (2) explicit conflict-prevention measures. Whilst the EC directly emphasises the security of its members in this endeavour, the World Bank and the UNDP avoid an explicit position depicting security in the Global North as threatened by conflict and violence in the Global South.

\section{Quantitative theoretical framework and hypotheses}

In order to assess the extent to which this policy discourse is reflected in practice, we investigate whether conflict-affected states receive more aid for the priorities identified by the multilateral donors as crucial to restoring peace and stability, than states that have not been affected by conflict. Specifically, we test whether the donors have, in the past two decades, committed relatively more aid to democratisation activities and to explicit conflict, peace and security activities in conflict-affected states than elsewhere.

As a second step in the analysis, we investigate whether conflict-affected states that are perceived to pose a higher threat in terms of the 'new' or unconventional transnational security concerns of terrorism and refugee movements receive more aid for democratisation or conflict prevention than conflict-affected states perceived to pose a lower threat. Both terrorism and refugee flows are, along with conflict and instability in the South, heavily 'securitised' within the development policy discourse of key Western bilateral donors including the US, the UK and Denmark ${ }^{37}$ as well as by the European Commission. ${ }^{38}$ By securitised we mean that both are understood to pose a potential national security threat and have been widely accepted as such, including in the UK's latest strategic defence and security review. ${ }^{39}$

The hypotheses, formulated on the basis of the donors' policy discourse, are as follows: 
H1: The EC, IDA, and UNDP channel relatively more aid to democratisation activities in conflict-affected states than elsewhere.

H2: The EC, IDA, and UNDP channel relatively more aid to conflict, peace, and security activities in conflict-affected states than elsewhere.

H3: The EC, IDA, and UNDP channel relatively more aid to democratisation activities in conflict-affected states that are perceived to pose a higher security threat by key Western donors.

H4: The EC, IDA, and UNDP channel relatively more aid to conflict, peace and security activities in conflict-affected states that are perceived to pose a higher security threat by key donors.

We strongly expect $\mathrm{H} 2$ to be confirmed by the data analysis, but include it as a first step towards testing $\mathrm{H} 4$, which will show the extent to which the security concerns of key Western donors affect the provision of conflict, peace, and security aid in conflict-affected states.

\section{Data and methodology}

\section{Dependent variables}

In testing the first hypothesis, our dependent variable is the proportion of development aid provided by each of the three multilateral donors to democratisation and institution-building activities ${ }^{40}$ (further referred to in this article as 'democratisation aid'). Specifically, these activities include support for democratic participation and civil society, legal and judicial development, legislatures and political parties, elections, anti-corruption, human rights, women's rights, and free media. When testing the second hypothesis, the dependent variable is the proportion of aid channelled to recipients' conflict, peace, and 
security activities ${ }^{41}$ (further referred to in this article as 'conflict, peace, and security aid'). This category comprises aid provision to security-system management and reform; civilian peacebuilding, conflict prevention and resolution; participation in international peacekeeping operations; reintegration and small-arms and light-weapons control; removal of landmines; and work with child soldiers.

We examine the donors' aid commitments rather than aid disbursements, for two reasons. First, OECD data on aid disbursements to different sectors are unreliable and available only after $2002 .{ }^{42}$ Second, aid commitments are subject to fewer arbitrary executive decisions and are less influenced by recipients' administrative capacity than aid disbursements. Consequently, they reflect donors' intentions more closely than disbursements. $^{43}$

\section{Main independent variables}

The main focus of this article is the impact of states' conflict-status, along with the extent to which they are understood to a pose security threat to the multilateral donors' main funders, on the proportion of aid committed by multilateral donors to democratisation and to conflict, peace, and security activities. States' conflict-status is approximated via three variables. The first is conflict intensity from the Uppsala University Conflict Data Programme (UCDP), which rates countries from zero (no conflict) to two (high conflict intensity). The second variable, post-conflict, is a binary variable of our own design, where countries are designated as post-conflict for five years following a descent from two to one and three years following a descent from one to zero on the UCDP conflict-intensity scale ${ }^{44}$. The last variable used to measure conflict affectedness, again constructed for the purpose of this research, measures the longer-term post-conflict period; i.e. five years after the end of the post-conflict period as long as no new conflict has erupted, and is referred to as 'LT postconflict'. This variable takes into account potential donors' concerns regarding the absorption 
capacity of recipients in or immediately after armed conflicts, particularly with regard to democratisation aid. We use the variable primarily as a robustness check.

The extent to which an aid recipient poses a potential security threat, in terms of new transnational security concerns, to the multilateral agencies main funders is operationalised using data on the number of refugees received by OECD/EU countries from each aid recipient in one year and the number of OECD/EU casualties from terrorist attacks in the aidrecipient country that year. This compound variable is utilised when testing hypotheses for the IDA and UNDP, with the rationale that OECD/EU states account for more than 95 per cent of the two institutions' regular funding. To reflect its membership, the European Commission's security threat variable for each aid recipient is computed from the number of refugees received from an aid-recipient state by EU member states only and the number of EU casualties from terrorist attacks in that state. Data on refugees were obtained from the United Nations High Commissioner on Refugees database and data on terrorist attacks from the Global Terrorism Database at the University of Maryland. The two data components were first standardised to zero-one values, then summed, and finally re-coded into a zero-three scale, where zero signifies none or low and three high security concerns for each aid agency.

The constituents of the security concern variable - refugee flows and terrorist attacks were chosen based on what donors identify as the key unconventional transnational security threats within the context of the security-development nexus, i.e. security threats that can be mitigated through development aid. As discussed, both migration and terrorism (along with conflict and instability in the Global South, which is already captured in the analysis) are identified as key global challenges by the multilateral donors' key funders including the UK and the US. ${ }^{45}$ However, because existing aid literature has conventionally utilised arms transfers as the approximation of countries' security concerns, ${ }^{46}$ as a robustness test we use an alternative security-concern variable that adds to the refugee and terrorist casualties data 
arms exports data as well (from EU countries for the EC and from OECD/EU countries for the IDA and UNDP). The alternative security-concern variable is similarly to the main security-concern variable coded on a scale from zero (no concern) to three (high concern).

\section{Control variables}

Following existing literature on aid allocation, ${ }^{47}$ our model further controls for recipient needs and donor interests other than security. Keeping in mind our overall focus on the proportion of aid committed to government and civil society (both conflict, peace, and security aid and democratisation aid fall under this remit) rather than total aid flows more commonly analysed by researchers, an obvious recipient need should be poor governance since we can expect countries with poor governance to potentially benefit the most from donor investments in their government and civil society sectors. We operationalise governance through the World Bank's Worldwide Governance Indicators (WGI). We also control for countries' GDP per capita, adjusted for purchasing power parity, and their population size, both obtained from the World Bank's World Development Indicators.

Turning to donor interests other than security, trade flows with recipients may influence donors' decisions vis-à-vis the proportion of aid committed to activities under the government and civil society sector - such investment could be seen as an incentive or reward to trading partners. Whilst such an effect can be expected to be weaker in the case of multilateral donors than bilateral ones, ${ }^{48}$ it is possible that the main funders of the multilateral agencies shape the agencies' aid allocations in line with their own commercial interests. Therefore, as further control variables we include measures of export and import flows between recipient countries and EU member states for the EC and between recipient countries and OECD/EU countries for the IDA and UNDP, all obtained from the International Monetary Fund's Direction of Trade Statistics. We also control for former 
colonial status and the region where each aid-recipient resides. Descriptive statistics of the control variables used are displayed in Table 3 in the Appendix.

\section{Dataset and methods}

The dataset used in this study covers 132 aid-recipient countries for 21 years (19952015). We chose 1995 as the lower cut-off year as this was when the policy discourse connecting development with security began to emerge, ${ }^{49}$ whilst 2015 is the most recent year for which aid data were available at the time of our research. In order to account for bureaucratic inertia in aid provision as well as for the fact that aid is often committed to projects and programmes several years in advance, the data are not analysed annually but averaged over seven three-year periods. As a robustness test, however, we also examine the relationship between a state's conflict-status and aid to conflict, peace, and security and to democratisation activities using two-year and four-year averaged data. Unlike annual data, the averaged data according to the Arellano-Bond tests are not serially correlated.

The selection of the appropriate empirical estimator is hence driven primarily by the censored nature of the data: they are downward-censored by zero, i.e. cannot take negative values, and as any measure of proportion upward-censored by one. As our main estimator, we hence use panel Tobit regressions with random dyad effects. ${ }^{50}$ All the regression models control for time trends through the inclusion of time-period dummy variables and use robust standard errors.

\section{Summary statistics}

Table 1 displays trends in the main dependent and independent variables for the first and last time periods examined. All three donors increased their average aid commitment per recipient from 1995-1997 to 2013-2015. The rate of increase has substantially differed, however, with the UNDP raising its aid provision by approximately a quarter, IDA by a half, 
and the EC by more than two times. All three donors also augmented their relative aid provision to democratisation and to conflict, peace, and security activities. Of the three donors, only the EC commits relatively more aid to conflict, peace, and security activities than to democratisation, whilst the UNDP invests relatively more in democratisation activities, with almost 45 per cent of its aid commitments going to that sector in the last wave of data examined (2013-2015).

\section{[Figure 1]}

Turning our attention to the key independent variables, the average conflict intensity declined over the two decades examined, from 0.28 to 0.18 , whilst the proportion of postconflict countries increased, from 12 to 16 per cent. Figure 1 demonstrates that the proportion of aid committed to post-conflict countries increased correspondingly, with the IDA providing the largest relative amount by 2015 . The proportion of long-term post-conflict countries, in contrast, decreased, from nine per cent in 1995-1997 to seven per cent in 20132015.

Regarding the security concern variables, in the first time period examined the average EU security concern variable was higher than the average OECD/EU security concern variable. By 2013-2015, however, the average aid recipient was of a higher security concern for all OECD/EU countries than for only EU member states. The alternative securityconcern variables, composed of data on refugees, casualties of terrorist attacks, as well as arms exports, have exhibited the same temporal trend.

[Table 1]

Summary statistics of the control variables, shown in Table 3 in the Appendix, demonstrate that aid recipients' GDP per capita along with EU and OECD/EU exports to and 
imports from aid-recipient countries on average increased in the two decades under observation. However, there has been no improvement in governance indicators.

\section{Results}

\section{The provision of democratisation aid (hypothesis 1)}

The left part of Table 2 assesses the first hypothesis - that the three multilateral donors, in line with their policy discourse, channel relatively more aid to democratisation activities in conflict-affected countries. Our results do not support the hypothesis. There is no significant relationship between aid recipients' conflict intensity or post-conflict status and the proportion of aid committed to democratisation activities by either the EC or the IDA, in spite of the policy discourse. A positive relationship does not appear even in the longer-term post-conflict period. The UNDP actually commits relatively less aid to democratisation activities in countries that have been affected by conflict than elsewhere. The securityconcern variables, both the main and alternative one, do not appear to significantly impact aid-allocation to democratisation activities by any of the three multilateral donors analysed.

Of the control variables employed, GDP per capita has a consistent negative effect on the proportion of aid provision to democratisation, aligning with our expectation vis-à-vis recipients' needs. The IDA and UNDP also commit more democratisation aid to recipients with whom the OECD/EU members have a stronger trading relationship whereas the EC does so for former European colonies. Countries with better governance receive significantly less democratisation aid from the EC than countries with poorer governance scores. Of the three donors, only the UNDP increased its relative provision of democratisation aid over time, although as the results above show, not to conflict-affected countries.

\section{The provision of conflict, peace, and security aid (hypothesis 2)}


The right part of Table 2 tests our second hypothesis, according to which the three multilateral donors, in line with their policy discourse, commit a higher proportion of aid to conflict, peace, and security activities in states affected by conflict. The results, as expected, strongly support this hypothesis. All the donors examined channel relatively more conflict, peace, and security aid to post-conflict countries and the EC and IDA also commit relatively more of such aid to countries presently involved in conflict. Unlike the other two donors, the EC continues to provide relatively more conflict, peace, and security aid to countries in the longer-term post-conflict period (five to ten years after the cessation of hostilities).

Our other key independent variable, security concern, exhibits a positive significant relationship with the three donors' conflict, peace, and security aid-proportion as well, whether measured through its main or its alternative form. This finding demonstrates that independent of aid recipients' conflict status, the EC, IDA, and UNDP channel relatively more conflict, peace, and security aid to countries in the Global South that constitute a higher transnational security risk for their main funders. Countries including Albania, Egypt, Lebanon or Kenya that are not affected by conflict but are of high security concern to OECD/EU donors receive significantly more multilateral conflict, peace, and security aid than countries such as Nicaragua, Niger, Madagascar, and Zambia that are similarly not at conflict but are of low security concern to OECD/EU countries.

[Table 2]

Regarding other factors affecting the dependent variable, quality of governance as measured by the WGI has a negative influence on the relative aid allocation to conflict, peace, and security activities by all three multilateral agencies but only in the case of the EC the relationship is significant. The EC, IDA, and UNDP also commit less conflict, peace, and security aid to economically more affluent countries. Finally, for the EC and UNDP there is a 
clear positive time trend throughout the two decades towards committing a higher proportion of aid to conflict, peace, and security activities, as was previously indicated by the summary statistics in Table 1.

The results in Table 2 do not point to the existence of any stark differences between the three different donors' aid commitments. Unlike the other two multilateral agencies, the UNDP provides less aid to democratisation activities in countries at conflict; however, neither the EC nor the IDA actually commit significantly more of such aid to conflictaffected countries as their discourse would suggest. This is not the case even in the longerterm post-conflict period, which we included in the model specifically to investigate whether concerns about absorptive capacity may have prevented the donors from increasing the relative provision of democratisation aid to countries in or straight after conflict. Nevertheless, the results do indicate that after hostilities cease in a given country, multilateral donors over time invest slightly more in democratisation activities there, with such trend most notable for the EC and least for the UNDP. In practice the UNDP appears to overlook the proclaimed importance of democratisation aid in conflict-affected states to a greater degree than the EC or IDA.

On the other hand, in line with the policy discourse, all three multilateral donors examined channel more conflict, peace, and security aid to conflict-affected countries. The EC and IDA do so both in conflict-involved and post-conflict countries whilst the UNDP commits relatively more conflict, peace, and security aid only to countries in the post-conflict period. Combined with its relatively weak commitment to democratisation aid in conflictaffected states, of the three donors the UNDP could be described as the least affected by the securitisation of aid. As discussed above, this may be indicative of the UNDPs universalist structure; Western concerns regarding conflict and instability in the South have less of an impact on its aid distribution. 
In order to assess the robustness of the findings discussed above, we estimated the same models with data averaged across two-year and four-year periods as well (see Table 4 in the Appendix). The results for the key variables - aid recipients' conflict status and level of security concern to Western donors - are in both direction and significance very similar to the ones attained with the three-year-averaged data in Table 2, supporting the overall validity of our findings.

\section{The impact of the transnational security concerns of Western states (hypotheses 3 and} 4)

The results from testing hypotheses 1 and 2 provide evidence that multilateral development aid to conflict-affected countries is focused on conflict, peace, and security activities but not on democratisation activities. Within the pool of conflict-affected states, however, some may be of significantly higher security interest than others for key Western funders of multilateral agencies. Accordingly, hypotheses 3 and 4 test whether conflictaffected countries of higher security concern to Western states receive proportionally more aid commitments to democratisation activities (hypothesis 3) and to conflict, peace, and security activities (hypothesis 4) than conflict-affected and post-conflict countries of lower security concern to key Western donors.

The left side of Table 5 in the Appendix shows that conflict-affected states of a high security concern for the multilateral agencies' key funders receive no more or less EC or UNDP democratisation aid than conflict-affected states of a comparatively lower security concern. Countries of higher OECD/EU security concern do receive considerably more conflict, peace, and security aid from the IDA, but neither the interactions of conflictaffectedness and security concerns nor their marginal effects appear statistically significant for any of the multilateral donors. 
[Figure 2]

However, Figure 2, based on the right part of Table 5 in the Appendix, shows that the proportion of aid committed to conflict, peace, and security activities in post-conflict states does vary with different degrees of security concern (testing hypothesis 4 ). The findings suggest that all three multilateral donors commit more conflict, peace, and security aid to conflict-affected recipients that are of higher security concern to Western states, i.e. the institutions' main funders, than to conflict-affected states that are of lower security concern. The conditioning effect of security concern is particularly strong for the EC and the UNDP. The EC commits significantly more conflict, peace, and security aid to conflict-affected countries of high security concern to the EU, whilst the UNDP does so for conflict-affected countries of moderate and high security concern to OECD/EU countries. The IDA does not seem to be influenced by aid recipients' security importance to the same degree as the other two donors, but post-conflict countries that are of the lowest security concern to OECD/EU members (score of zero) do not receive significantly more conflict, peace, and security aid from the IDA than states not affected by conflict, unlike post-conflict countries of higher security concern.

\section{Multilateral aid and the security-development nexus}

Since the mid-1990s, development and security have been considered as mutually constitutive by major OECD donors, with development aid understood as having a central role to play in the creation of peaceful, stable societies. We have found this to be true for multilateral donors as well. The European Commission, World Bank, and United Nations Development Programme emphasise two approaches through which aid can help strengthen security in the Global South: (1) investing in creating democratic, rights-respecting, inclusive societies, which are understood to have the characteristics necessary to deal with conflict in 
nonviolent ways and (2) investing in 'conflict, peace, and security' programmes, which include civilian peacebuilding, conflict prevention and resolution, reintegration of soldiers, and security-sector reform. Having established this context, this article went on to examine the extent to which the policy discourse is reflected in actual aid commitments. Furthermore, because for many Western states the security-development nexus is underpinned by the assumption that conflict and instability in the Global South are a threat to their national security, this research also assessed whether the security concerns of the key funders of multilateral aid agencies have impacted multilateral funding in conflict-affected states.

Whilst all three multilateral donors strongly uphold the position that building states with robust institutions which respect human rights is fundamental to creating a lasting 'liberal peace' in areas affected by conflict, our results demonstrate that this is not mirrored in actual aid provision. Neither the EC nor the IDA have provided proportionally more democratisation aid to conflict-affected or post-conflict countries than elsewhere and the UNDP has committed less democratisation aid to countries involved in active conflict.

As a second step in our analysis, we tested whether conflict-affected countries receive proportionally more aid to conflict, peace, and security activities, which were also highlighted as necessary in reducing conflict and strengthening security in the policy discourse (hypothesis 2). The results have provided robust support to this expectation; all three donors channel more conflict, peace, and security aid to post-conflict countries and the EC and IDA also to countries at conflict. Whilst this result was expected, it may be understood within the context of a wider trend towards the securitisation of aid flows. Official development assistance is defined by its 'promotion of the economic development and welfare of developing countries ${ }^{, 51}$ and it was not until the mid-2000s that the definition of ODA was widened to include expenditures under the fields of conflict, peace, and security. Such expenditures would previously have been taken from different government budgets 
rather than aid. ${ }^{52}$ The expansion of what can be defined as development aid may be suggestive of this trend.

Although the multilateral donors examined, particularly the IDA and the UNDP, have in theory an obligation to be impartial ${ }^{53}$, they have often been observed to align their aid disbursements with their main funders' interests. ${ }^{54}$ Hypotheses 3 and 4 thus conjectured that the trend towards the securitisation of development by key bilateral donors may impact multilateral aid commitments in conflict-affected states of higher security interests to the donors' key funders - the EU member states in the case of the EC and OECD and EU member countries in the case of the IDA and UNDP. In line with the donors' policy discourse, we operationalised the security-concern variable on the basis of compound refugee flows and terrorist casualties. We tested the robustness of such-attained results with the inclusion of an alternative security-concern variable that comprises arms-transfers data in addition to the data on terrorist incidents and refugee flows.

The behaviour of all three multilateral donors confirmed the hypothesis in the case of conflict, peace, and security aid. In other words, the EC, IDA and UNDP commit relatively more aid to conflict, peace, and security activities in those conflict-affected countries that are of a higher security concern to their main funders (e.g. Sudan, Colombia, the Democratic Republic of Congo) than in conflict-affected countries of lower security concern (e.g. Chad, Mozambique, Tajikistan). In contrast, whether recipients are of a high or low security concern does not play a significant role when it comes to donor decisions about democratisation-aid commitments in conflict-affected countries.

These results indicate that there is a gap between the policy discourse and aid commitments: whilst the policy discourse highlights democratisation activities as essential to creating and sustaining peace and stability in the global South, conflict-affected states, even those in a longer-term post-conflict phase, receive no more funding for democratisation 
activities than states not affected by conflict. At the same time, however, the results suggest that multilateral aid commitments to conflict-resolution and prevention activities not only reflect donors' discourse but are also influenced by the security concerns of Western states.

\section{Conclusions}

This article has demonstrated that, in line with the rhetoric of key bilateral donors, the policy discourse of multilateral donors to some extent reflects the security-development nexus. Security and development in the Global South are understood as indivisible and, for the EC, linked to the security of its member states. However, there is a significant disconnect between the multilateral policy discourse and actual aid commitments. Furthermore, the influence of Western states on multilateral aid provision to conflict-affected states is apparent. The implications of these results are explored below.

First, they show that with regard to the provision of multilateral aid to conflictaffected countries, as in many other areas, ${ }^{55}$ there is a considerable gap between donors' expressed priorities and actual aid flows. Over the last two decades, academics and the NGO community have been increasingly concerned about the effects of the security-development nexus on development outcomes. Our finding that aid provided by three major multilateral donors is channelled to conflict, peace, and security activities, but fails to underpin the establishment of democratic, inclusive societies in conflict-affected states is unlikely to alleviate these concerns.

These findings may reflect the short-termist nature of aid programming, as identified by Denney, ${ }^{56}$ with donors more willing to invest in conflict-resolution activities deemed to yield quick results than in initiatives requiring longer-term investment. ${ }^{57}$ In the case of the European Union, our results chime with Furness and Gänzle's observation that the EU's External Action Service 'has continued to focus on immediate threats rather than on longterm development challenges ${ }^{98}$ as well as with Del Biondo and Orbie's ${ }^{59}$ finding that despite 
the rhetorical importance placed on democracy promotion through aid, the European Commission often foregoes this goal to pursue more immediate aims. Similar conclusions have been reached vis-à-vis the World Bank's and UNDP's aid-provision trends. ${ }^{60}$ Such donor behaviour runs contrary to research suggesting that only long-term solutions can bring about sustainable peace ${ }^{61}$ and that prioritising narrow security objectives actually leads to the marginalisation of female and minority rights. ${ }^{62}$ As Brown et al. ${ }^{63}$ illustrate, when Western security forces used aid to promote short-term national security interests in Afghanistan, long-term development did not follow; rather, the way in which aid was distributed created local frustration with wasted resources and increased corruption.

In addition it is recognised amongst practitioners and academics that development agencies are under pressure to demonstrate positive development aid results ${ }^{64}$, i.e. to show that 'aid works'. It may be difficult to yield demonstrably positive development outcomes through investing in democratisation programmes in conflict-affected states. In Sierra Leone, for example, a programme to reform the chieftaincy system was abandoned because it was too complex and challenging to yield results in the short term. ${ }^{65}$ In addition, aid agencies are under pressure to demonstrate value for money and efficiency in the design of projects and programmes. ${ }^{66}$ This pressure may result in aid for democratisation being channelled to areas where value for money can be demonstrated more easily, rather than to complex environments affected by conflict and instability in which value for money may be hard to establish.

These finding are in line with Crawford, who found donors' democracy promotion in Ghana to be 'high on rhetoric but...low on delivery' ${ }^{67}$ In view of Ghana's favourable political environment in which to strengthen democracy, Crawford ${ }^{68}$ suggests that donors' commitment to democracy promotion is unlikely to be stronger in less favourable environments, which would include conflict-affected and post-conflict states. Crawford 
identifies three possible reasons for his finding: donors' reluctance to shift away from traditional aid programmes oriented towards socio-economic development; a focus on security and stability; and that donors' interest in democracy is limited to minimising government rather than deepening and widening participation in political processes. The latter, it is argued, results in a focus on technical good governments (or public sector reform) and decentralisation. This may explain why the EC, IDA, and UNDP have failed to provide more democratisation aid to conflict-affected countries, despite discourse to the contrary: the donor-preferred technical 'democratisation' activities are not suitable and often not possible to implement in fragile, conflict-affected environments, where state capacity needs to be strengthened and unity rather than decentralisation promoted.

Our findings further demonstrate that despite World Bank and UNDP statements to the contrary, they, along with the EC, reflect the transnational security concerns of their main funders in their aid commitments to conflict-affected states. This finding adds weight to arguments that these institutions mirror Western interests in their policies and practice and demonstrates how Western donors use a variety of channels to influence outcomes in conflict-affected states deemed to be of security concern.

However, the extent to which this practice might influence development and policy outcomes in conflict-affected states depending on their apparent security interest to the West needs further investigation. Whether or not conflict-affected countries of lower security concern are disadvantaged because they receive relatively less conflict, peace, and security aid than countries of higher security concern is thus far, unclear. The short-termist nature of such aid and its potential to exacerbate conflict, as noted above, may indicate that they are not, but this requires further research.

In conclusion, the impact of the security-development nexus on multilateral aid commitments to conflict-affected states is nuanced, with a differentiated impact on discourse 
and on investment in different types of projects in different states depending on the extent to

which they are a security concern to the donors' main funders. In light of our results

demonstrating increasing conflict, peace, and security aid in strategically more important

states without the corresponding investment in long-term democratisation, we suggest further

research into the rationale, interests, and bureaucracies underpinning these trends and into the effects of such trends on development outcomes within the Global South.

\footnotetext{
${ }^{1}$ Brown and Gravingholt, The Securitisation of Foreign Aid; Duffield, Global Governance and the New Wars; McConnon, 'Security for All, Development for Some?', Spear, 'The Militarisation of US Foreign Aid'.

${ }^{2}$ E.g. DFID, Operational Plan 2012-2015; USAID, USAID Strategy on Democracy, Human Rights, and Governance, i.

${ }^{3}$ Brown et al. 'The Securitisation of Foreign Aid'; Oxfam, Whose Aid Is It Anyway?

${ }^{4}$ Suhrke and Buckmaster, 'Aid, Growth, and Peace', 340.

5 Thomas, 'Global Governance, Development, and Human Security'; Cliffe et al., Community-Driven Reconstruction as an Instrument in War-to-Peace Transitions; Beall et al., 'On the Discourse of Terrorism, Security, and Development'; Duffield, 'The Liberal Way of Development and the Development-Security Impasse'.

6 The World Bank's main funding tool for developing countries

${ }^{7}$ Asher, 'Multilateral versus Bilateral aid'; Maizels and Nissanke, 'Motivations for Aid to Developing Coutnries'; Burnside and Dollar, 'Aid, Policies, and Growth'; Petrikova, 'Promoting "Good Behaviour” through Aid'.

${ }^{8}$ The World Bank, the International Monetary Fund, and the World Trade Organisation

${ }^{9}$ Neumayer, 'Is Respect for Human Rights Rewarded?'; Berthelemy, 'Bilateral Donors' Interest vs. Recipients' Development Motives in Aid Allocation'; Lebovic and Voeten, 'The Cost of Shame'.

${ }^{10}$ Ferguson, The Anti-Politics Machine; Escobar, Encountering Development.

${ }^{11} \mathrm{https}$ ///ida.worldbank.org/sites/default/files/pdfs/ida17-contributions.pdf; the US, UK, Germany, and France are amongst the top five largest funders.

12 Overbeek, 'Global Governance, Class, Hegemony'; Lebovic and Voeten, 'The Cost of Shame'.

1398 per cent of UNDP's regular funding in 2016 was provided by OECD/EU countries: http://open.undp.org/\# top-donors/ regular; the US, UK, Sweden, and Norway were amongst the top five funders in that year.

${ }^{14}$ E.g. Barnett and Finnemore, 'The Power of Liberal International Organisations'.

${ }^{15}$ Berthelemy, 'Bilateral Donors' Interest vs. Recipients' Development Motives in Aid Allocation'.

${ }^{16}$ Ibid.

${ }^{17}$ McLean, 'Donor's Preferences and Agent Choice'; Schneider and Tobin, 'Interest Coalitions and Multilateral Aid Allocation in the European Union'.

${ }^{18}$ Furness and Gänzle, 'The European Union's Development Policy'.

${ }^{19}$ By securitisation we are referring to the trend towards linking development in the Global South to security in the Global North (or West). As such conflict and instability in the Global South are conceptualised as potential threats to the Global North which can be mitigate through 'development'. See for example Thomas, 'Global Governance, Development, and Human Security'; Beall et al., 'On the Discourse of Terrorism, Security, and Development'; Duffield, 'The Liberal Way of Development and the Development-Security Impasse'.

${ }^{20}$ Tracy, Qualitative Research Methods.

${ }^{21}$ DG Development, Securing Peace and Stability for Africa, 1; World Bank, The Role of the World Bank in Conflict and Development, 17; UNDP, Conflict Prevention and Peacebuilding; UNDP, Securing Development, 14-15; World Bank, Conflict Prevention and Reconstruction; UNDP, 2009 Annual Report; European Commission, Increasing the Impact of EU Development Policy; European Commission, STRIVE for Development, 2, 8, 11; European Commission, Strategic Plan 2016-2020, 7,10; World Bank, El Fondo del Banco Mundial para los Más Pobres; World Bank, World Bank Group Engagement in Situations of Fragility, Conflict, and Violence.
} 
${ }^{22}$ E.g. DG Development, Securing Peace and Stability for Africa; European Commission, Shared Vision, Common Action, 1, 14, 16, 28. See also Council, European Parliament and European Commission, The New European Consensus on Development.

${ }^{23}$ European Commission, Shared Vision, Common Action, 11. See also Council, European Parliament and European Commission, The New European Consensus on Development, 4.

${ }^{24}$ UNDP, UNDP Policy and Programme Brief, 4. See also UNDP, Building Inclusive Societies and Sustaining Peace.

${ }^{25}$ UNDP, UNDP Policy and Programme Brief, 4

${ }^{26}$ DG Development, Securing Peace and Stability for Africa; European Commission, Shared Vision, Common Action, 1, 14, 16, 28. See also Council, European Parliament and European Commission, The New European Consensus on Development.

${ }^{27}$ World Bank, Conflict, Security, and Development.

${ }^{28}$ Ibid, 1.

${ }^{29}$ European Commission 2006, A Concept for European Community Support for Security Sector Reform, 8; European Commission, Shared Vision, Common Action, 1, 14, 31; European Commission, STRIVE for Development, 3; European Commission, Strategic Plan 2016-2020, 8; UNDP, Building Inclusive Societies and Sustaining Peace, World Bank, World Bank Group Engagement in Situations of Fragility, Conflict, and Violence.

${ }^{30}$ UNDP, Building Inclusive Societies and Sustaining Peace, 13.

${ }^{31}$ E.g. Danida, A World of Difference, 2; Operational Plan 2012-2015; USAID, USAID Strategy on Democracy, Human Rights, and Governance, i.

${ }^{32}$ UNDP, UNDP Policy and Programme Brief, 11. See also European Commission, Shared Vision, Common Action, 31; European Commission, STRIVE for Development, 3, 8; Council, European Parliament, and European Commission, The New European Consensus on Development, 32; UNDP 2016, UNDP Policy and Programme Brief, 16.

${ }^{33}$ European Commission, STRIVE for Development, $3,8$.

${ }^{34}$ World Bank, World Bank Group Engagement in Situations of Fragility, Conflict, and Violence, 2. See also World Bank, Conflict, Security, and Development.

${ }^{35}$ World Bank, Conflict, Security, and Development; UNDP, UNDP Policy and Programme Brief; UNDP, Building Inclusive Societies and Sustaining Peace.

${ }^{36}$ UNDP, 2004 Report; European Commission, A Concept for European Community Support for Security Sector Reform.

${ }^{37}$ Danida, Africa - Development and Security, 9; DFID, Fighting Poverty to Build a Safer World, 3-5; DFID, Operational Plan 2012-2015, 2; USAID, USAID Policy Framework 2011-2015, 1; USAID, USAID Strategy on Democracy, Human Rights, and Governance,30; Greening, 'UK Aid in 2015', 7-8; Greening, 'Changing World, Changing Aid', 2.

${ }^{38}$ DG Development, Securing Peace and Stability for Africa; European Commission, Shared Vision, Common Action, 1, 14, 16, 28. See also Council, European Parliament and European Commission, The New European Consensus on Development,

${ }^{39}$ HM Government National Security Strategy and Strategic Defence and Security Review 2015 A Secure and Prosperous United Kingdom.

${ }^{40}$ Classified by the Creditor Reporting System (CRS) of the OECD aid database under the code 152: I.5.a

${ }^{41}$ Classified in the CRS under the code 152: I.5.b

${ }^{42}$ Petrikova, 'Promoting "Good Behaviour" through Aid'.

${ }^{43}$ Berthelemy, 'Bilateral Donors' Interest vs. Recipients' Development Motives in Aid Allocation'.

${ }^{44}$ Initially, we utilised two further measures - the number of conflict-related deaths per country per year (available from UCDP) and the Fragile States Index rating compiled by the Fund for Peace since 2006. In the final models, we decided against using the number-of-deaths variable due to its consistently similar but slightly less significant results than those obtained with the conflict-intensity measure. We chose not to utilise the Fragile States Index as it is unavailability prior to 2006, which severely limited our sample.

${ }^{45}$ DG Development, Securing Peace and Stability for Africa; HM Treasury and DFID, UK Aid; World Bank, Conflict, Security, and Development; European Commission, Shared Vision, Common Action.

${ }^{46}$ E.g. Maizels and Nissanke, 'Motivations for Aid to Developing Coutnries'; Neumayer, 'Is Respect for Human Rights Rewarded?'.

${ }^{47}$ E.g. Neumayer, 'Is Respect for Human Rights Rewarded?'; Nielsen, 'Rewarding Human Rights?'; Petrikova, 'Promoting "Good Behaviour" through Aid'.

${ }^{48}$ E.g. Burnside and Dollar, 'Aid, Policies, and Growth'.

${ }^{49}$ Duffield, Global Governance and the New Wars.

${ }^{50}$ This is discussed in more detail by, for example, Nielsen, 'Rewarding Human Rights?' 
${ }^{51} \mathrm{OECD}$, Is It ODA?, 1.

${ }^{52}$ Hynes and Scott, 'The Evolution of Official Development Assistance', 11.

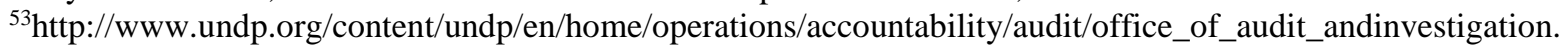
html, http://ewebapps.worldbank.org/apps/ip/Pages/AboutUs.aspx

${ }^{54}$ E.g. Neumayer, 'Is Respect for Human Rights Rewarded?', Lebovic and Voeten, 'The Cost of Shame'.

${ }^{55}$ Easterly and Williamson, 'Rhetoric versus Reality', 1930.

${ }^{56}$ Denney, 'The Militarisation of Foreign Aid'.

${ }^{57}$ Bilgin and Morton, 'From "Rogue" to "Failed" States?', 169-170.

${ }^{58}$ Furness and Gänzle, 'The European Union's Development Policy', 14.

${ }^{59}$ Del Biondo and Orbie, 'The European Commission's Implementation of Budget Support'.

${ }^{60}$ Grindle, 'Good Governance'; Burnell, 'From Evaluating Democracy Assistance'.

${ }^{61}$ Suhrke and Buckmaster, 'Aid, Growth, and Peace'.

${ }^{62}$ Oxfam, Whose Aid Is It Anyway?, 7.

${ }^{63}$ Brown et al., 'The Securitisation of Foreign Aid', 241.

${ }^{64}$ Denney, 'Liberal Chiefs or Illiberal Development?'; Yanguas and Hulme, 'Barriers to Political Analysis in Aid Bureaucracies'.

${ }^{65}$ Denney, 'Liberal Chiefs or Illiberal Development?'.

${ }^{66}$ Yanguas and Hulme, 'Barriers to Political Analysis in Aid Bureaucracies'.

${ }^{67}$ Crawford, 'The European Union and Democracy Promotion in Africa', 571.

${ }^{68}$ Ibid. 


\section{Bibliography}

Asher, Robert E., 1962. 'Multilateral versus Bilateral aid: An Old Controversy Revisited'. International Organisation 16(4), 697-719.

Barnett, Michael and Martha Finnemore, 2005. 'The Power of Liberal International Organisations'. In Power in Global Governance, eds. Michael Barnett and Raymond Duvall. Cambridge University Press, Cambridge, 161-184.

Beall, Jo, Thomas Goodfellow and James Putzel, 2005. 'Introductory Article: On the Discourse of Terrorism, Security, and Development'. Journal of International Development 18(1), 5-67.

Berthelemy, Jean-Claude, 2006. 'Bilateral Donors' Interest vs. Recipients' Development Motives in Aid Allocation: Do All Donors Behave the Same? Review of Development Economics 10(2), 179-194.

Bilgin, Pinar and Adam D. Morton, 2004. 'From "Rogue" to "Failed" States? The Fallacy of Short-Termism'. Politics 24(3), 169-180.

Brown, Stephen and Jorn Gravingholt, 2016. The Securitisation of Foreign Aid. Palgrave Macmillan, Basingstoke.

Brown, Stephen, Jorn Gravingholt and Rosalind Raddatz, 2016. 'The Securitisation of Foreign Aid: Trends, Explanations, and Prospects'. In The Securitisation of Foreign Aid, eds Stephen Brown and Jorn Gravingholt. Palgrave Macmillan, Basingstoke, 237255.

Burnell, Peter, 2008. 'From Evaluating Democracy Assistance to Appraising Democracy Promotion'. Political Studies 56(2), 414-434.

Burnside, Craig and David Dollar, 2000. 'Aid, Policies, and Growth'. American Economic Review 90(4), 847-868. 
Cliffe, Sarah, Scott Guggenheim and Markus Kostner, 2003. Community-Driven

Reconstruction as an Instrument in War-to-Peace Transitions. The World Bank Group, Washington, DC.

Collier, Paul, Lani Elliott, Havard Hegre, Anke Hoeffler, Marta Reynal-Querol and Nicholas Sambanis, 2003. Breaking the Conflict Trap. The World Bank Group, Washington, DC. Available at:

https://openknowledge.worldbank.org/bitstream/handle/10986/13938/567930PUB0brea 10Box353739B01PUBLIC1.pdf [Accessed 16 May 2017]

Council, European Parliament and European Commission, 2017. The New European Consensus on Development - Our World, Our Dignity, Our Future. Joint Statement by the Council and the Representative of the Governments of the Member States meeting with the Council, the European Parliament and the European Commission. $7_{\text {th }}$ June 2017 Crawford, Gordon, 2005. 'The European Union and Democracy Promotion in Africa: The Case of Ghana'. The European Journal of Development Research 17(4), 571-600.

Danida, 2003. A World of Difference: The Government's Vision for New Priorities in Danish Development Assistance 2004-2008. Royal Danish Ministry of Foreign Affairs, Copenhagen.

Danida, 2005. Africa - Development and Security: The Government's Priorities for Danish Cooperation with Africa 2005-2009. Royal Danish Ministry of Foreign Affairs, Copenhagen.

DG Development, 2004. Securing Peace and Stability for Africa. The EU-Funded African Peace Facility. European Commission, Brussels.

Del Biondo, Karen and Jan Orbie, 2014. 'The European Commission's Implementation of Budget Support and the Governance Incentive Tranche in Ethiopia: Democracy Promoter or Developmental Donor?' Third World Quarterly 35(3), 411-427. 
Denney, Lisa, 2012. 'The Militarisation of Foreign Aid'. Contemporary Review 294(1704), 29-38.

Denney, Lisa, 2013. 'Liberal Chiefs or Illiberal Development? The Challenge of Engaging Chiefs in DFID's Security Sector Reform Programme in Sierra Leone'. Development Policy Review 31(1), 5-25.

DFID, 2005. Fighting Poverty to Build a Safer World. A Strategy for Security and Development. DFID, London.

DFID, 2012. Operational Plan 2012-2015. DFID, London.

Duffield, Mark, 2001. Global Governance and the New Wars: The Merging of Development and Security. Zed Books Ltd, London.

Duffield, Mark, 2010. 'The Liberal Way of Development and the Development-Security Impasse: Exploring the Global Life-Chance Divide'. Security Dialogue 41(1), 53-76. Easterly, William and Claudia R. Williamson, 2011. 'Rhetoric versus Reality: The Best and Worst of Aid Agency Practices'. World Development 39(11), 1930-1949.

Escobar, Arturo, 1995. Encountering Development: The Making and Unmaking of the Third World. Princeton University Press, Princeton, NJ.

European Commission, 2006. Communication from the Commission to the Council and the European Parliament: A Concept for European Community Support for Security Sector Reform. European Commission, Brussels.

European Commission, 2011. Increasing the Impact of EU Development Policy: An Agenda for Change. European Commission, Brussels.

European Commission, 2016a. Shared Vision, Common Action: A stronger Europe. A Global Strategy for the European Union's Foreign and Security Policy. Available at: http://eeas.europa.eu/archives/docs/top_stories/pdf/eugs_review_web.pdf [Accessed 17 May 2017] 
European Commission, 2016b. STRIVE for Development. Strengthening Resilience to Violence and Extremism. European Commission, Brussels.

European Commission, 2016c. Strategic Plan 2016-2020. DG International Cooperation and Development DG DEVCO. European Commission, Brussels.

Ferguson, J. 1994. The Anti-Politics Machine: Development, De-Politicisation, and

Bureaucratic Power in Lesotho. University of Minnesota Press, Minneapolis, MN.

Furness, Mark and Stefan Gänzle, 2016. ‘The European Union’s Development Policy: A

Balancing Act between "A More Comprehensive Approach” and Creeping

Securitisation'. In The Securitisation of Foreign Aid, Stephen Brown and Jorn

Gravingholt. Palgrave Macmillan, Basingstoke, 138-162.

Greening, Justine, 2015a. 'UK Aid in 2015: The Progress So Far and the Priorities Ahead'. Speech given to the Institute of Development Studies, Brighton.

Greening, Justine, 2015b. 'Changing World, Changing Aid: Where International Development Needs to Go Next'. Speech given to the Overseas Development Institute, London.

Grindle, Merilee, 2012. 'Good Governance: The Inflation of an Idea." Planning Ideas that Matter. Harvard University, Cambridge, MA, 259-282.

HM Government, 2015. National Security Strategy and Strategic Defence and Security Review 2015 A Secure and Prosperous United Kingdom. HM Government, London HM Treasury and DFID, 2015. UK Aid: Tackling Global Challenges in the National Interest. HM Treasury, London.

Howard, Lisa M., 2015. 'US Foreign Policy Habits in Ethnic Conflict'. International Studies Quarterly 59(4), 721-734. 
Hynes, William and Simon Scott, 2013. 'The Evolution of Official Development Assistance: Achievements, Criticisms and a Way Forward'. OECD Development Co-operation Working Papers, No. 12, OECD Publishing.

Lebovic, James H. and Erik Voeten, 2009. 'The Cost of Shame: International Organisations and Foreign Aid in the Punishing of Human Rights Violators'. Journal of Peace Research 46(1), 79-97.

Maizels, Alfred and Machiko K. Nissanke, 1984. 'Motivations for Aid to Developing Countries'. World Development 12(9), 879-900.

McConnon, Eamonn, 2014. 'Security for All, Development for Some? The Incorporation of Security in UK's Development Policy'. Journal of International Development 26(8), $1127-1148$.

McLean, Elena, 2012. 'Donor's Preferences and Agent Choice: Delegation of European Development Aid'. International Studies Quarterly 56(1), 381-395.

Neumayer, Eric, 2003. 'Is Respect for Human Rights Rewarded? An Analysis of Total Bilateral and Multilateral Aid Flows'. Human Rights Quarterly 25(2), 510-527.

Nielsen, Richard A., 2013. 'Rewarding Human Rights? Selective Aid Sanctions against Repressive States'. International Studies Quarterly 57(4), 791-803.

OECD, 2008. 'Is it ODA? Factsheet - November 2008'. Available at: www.oecd.org/dac/stats [Accessed 7 September 2016]

Overbeek, Henk, 2005. 'Global Governance, Class, Hegemony: A Historical Materialist Perspective. In Contending Perspectives on Global Governance: Coherence, Contestation and World Order, eds. Alice D. Ba and Matthew J. Hoffmann. Routledge, London, 39-56.

Oxfam, 2011. Whose Aid Is It Anyway? Politicising Aid in Conflict and Crisis. Oxfam, Oxford. 
Petrikova, Ivica, 2016. 'Promoting "Good Behaviour" through Aid: Do "New” Donors Differ from the "Old" Ones? Journal of International Relations and Development 19(1), 153 192.

Schneider, Christina J. and Jennifer L. Tobin, 2013. 'Interest Coalitions and Multilateral Aid Allocation in the European Union'. International Studies Quarterly 57(1), 103-114.

Spear, Joanna, 2016. 'The militarisation of United States Foreign Aid. In The Securitisation of Foreign Aid, Stephen Brown and Jorn Gravingholt. Palgrave Macmillan, Basingstoke, 18-41.

Suhrke, Astri and Julia Buckmaster, 2006. 'Aid, Growth, and Peace: A Comparative Analysis'. Conflict, Security and Development 6(3), 337-363.

Thomas, Caroline, 2001. 'Global Governance, Development, and Human Security: Exploring the Links'. Third World Quarterly 22(2), 159-175.

Tracy, Sarah J, 2012. Qualitative Research Methods: Collecting Evidence, Crafting Analysis, Communicating Impact. John Wiley \& Sons, London.

UNDP, 2005a. Conflict Prevention and Peacebuilding. UNDP, New York, NY.

UNDP, 2005b. Securing Development: UNDP's Support for Addressing Small Arms Issues. UNDP, New York, NY.

UNDP, 2005c. 2004 Report: Thematic Trust Fund for Crisis Prevention and Recovery. UNDP, Washington, DC.

UNDP, 2009. 2009 Annual Report. UNDP, Washington, DC.

UNDP, 2016a. UNDP Policy and Programme Brief. UNDP Support to the Implementation of the 2030 Agenda for Sustainable Development. UNDP, New York, NY.

UNDP, 2016b. Building Inclusive Societies and Sustaining Peace through Democratic Governance and Conflict Prevention. UNDP, New York, NY.

USAID, 2011. USAID Policy Framework 2011-2015. USAID, Washington, DC. 
USAID, 2013. USAID Strategy on Democracy, Human Rights, and Governance. USAID, Washington, DC.

Uvin, Peter, 2004. Human Rights and Development. Kumarian Press, Sterling, VA.

Williams, Paul D., 2008. 'Keeping the Peace in Africa: Why “African” Solutions Are Not Enough'. Ethics and International Affairs 22(3), 309-329.

World Bank, 2004. The Role of the World Bank in Conflict and Development: An Evolving Agenda. The World Bank Group, Washington, DC.

World Bank, 2007. Conflict Prevention and Reconstruction. The World Bank Group, Washington, DC.

World Bank, 2011. World Development Report: Conflict, Security, and Development. The World Bank Group, Washington, DC.

World Bank, 2016a. El Fondo del Banco Mundial para los Más Pobres. The World Bank Group, Washington, DC.

World Bank, 2016b. World Bank Group Engagement in Situations of Fragility, Conflict, and Violence. The World Bank Group, Washington, DC.

Yanguas, Pablo and David Hulme, 2015. 'Barriers to Political Analysis in Aid Bureaucracies: From Principle to Practice in DFID and the World Bank'. World Development 74, 209219. 